\title{
COMPARISON OF SKIN MOISTURIZER: CONSUMER-BASED BRAND EQUITY (CBBE) FACTORS IN CLUSTERS BASED ON CONSUMER ETHNOCENTRISM
}

\author{
Yossy Hanna Garlina \\ PT Mustika Ratu, Tbk. \\ Jln. Raya Bogor Km 26,4, Ciracas, Jakarta 13740 \\ yossyhannagarlina@gmail.com
}

\begin{abstract}
This research aims to analyze relevant factors contributing to the four dimensions of consumer-based brand equity in skin moisturizer industry. It is then followed by the clustering of female consumers of skin moisturizer based on ethnocentrism and differentiating each cluster's consumer-based brand equity dimensions towards a domestic skin moisturizer brand Mustika Ratu, skin moisturizer. Research used descriptive survey method analysis. Primary data was obtained through questionnaire distribution to 70 female respondents for factor analysis and 120 female respondents for cluster analysis and one way analysis of variance (ANOVA). This research employed factor analysis to obtain relevant factors contributing to the five dimensions of consumerbased brand equity in skin moisturizer industry. Cluster analysis and one way analysis of variance (ANOVA) were to see the difference of consumer-based brand equity between highly ethnocentric consumer and low ethnocentric consumer towards the same skin moisturizer domestic brand, Mustika Ratu skin moisturizer. Research found in all individual dimension analysis, all variable means and individual means show distinct difference between the high ethnocentric consumer and the low ethnocentric consumer. The low ethnocentric consumer cluster tends to be lower in mean score of Brand Loyalty, Perceived Quality, Brand Awareness, Brand Association, and Overall Brand Equity than the high ethnocentric consumer cluster. Research concludes consumer ethnocentrism is positively correlated with preferences towards domestic products and negatively correlated with foreign-made product preference. It is, then, highly ethnocentric consumers have positive perception towards domestic product.
\end{abstract}

Keywords: exploratory factor analysis, K-means cluster, one-way ANOVA, skin moisturizer

\begin{abstract}
ABSTRAK
Penelitian bertujuan untuk menganalisis faktor-faktor relevan yang berkontribusi terhadap empat dimensi ekuitas merek berbasis konsumen dalam industri pelembab kulit. Kemudian, penelitian mengelompokkan konsumen pelembab kulit (wanita) berdasarkan etnosentrisme dan membedakan dimensi ekuitas merek berbasis konsumen setiap rumpun terhadap merek pelembab kulit dalam negeri, Mustika Ratu. Penelitian menggunakan metode analisis survei deskriptif. Data primer diperoleh melalui penyebaran kuesioner kepada 70 responden perempuan untuk analisis faktor dan 120 responden perempuan untuk analisis rumpun dan analisis varians satu jalur (ANOVA). Penelitian menggunakan analisis faktor untuk memperoleh faktor relevan yang berkontribusi terhadap lima dimensi ekuitas merek berbasis konsumen dalam industri pelembab kulit. Analisis rumpun dan analisis varians satu jalur (ANOVA) adalah untuk melihat perbedaan ekuitas merek berbasis konsumen antara konsumen dengan etnosentrisme tinggi dan konsumen dengan etnosentrisme rendah terhadap merek pelembab kulit dalam negeri yang sama, Mustika Ratu. Penelitian menemukan pada semua analisis dimensi, semua rata-rata variabel dan individual menunjukkan perbedaan jelas antara konsumen etnosentris tinggi dan konsumen etnosentris rendah. Skor Brand Loyalty, Perceived Quality, Brand Awareness, Brand Association, dan Overall Brand Equity konsumen etnosentris rendah cenderung lebih rendah daripada konsumen etnosentris tinggi. Penelitian menyimpulkan etnosentrisme konsumen berkorelasi positif dengan preferensi terhadap produk dalam negeri dan berkorelasi negatif dengan preferensi produk buatan luar negeri. Dengan kata lain, konsumen dengan etnosentrisme tinggi memiliki persepsi positif terhadap produk domestik.
\end{abstract}

Kata kunci: analisis faktor eksplorasi, K-means cluster, ANOVA satu jalur, pelembab kulit 


\section{INTRODUCTION}

In the era of globalization, consumer ethnocentrism is deemed as a very strategic tool to face the global competition. This is especially applicable to domestic companies as they are the ones facing the steep competition from foreign brands. The competition between local and foreign brands has been even steeper in 2010 and above, as the price difference has narrowed and the difference in quality has widened. As proven by a survey by Jakarta Post, Indonesian women inherently prefer "value for money", "quality brand", "proven benefits", "gentleness" and most importantly, "made in Indonesia". This survey proved that Indonesian women indeed love Indonesian made products. However, a different study conducted by Jakarta Post to verify this shows a different result. Local brands only hold merely less than $40 \%$ of the market share in Indonesian face and body care industry, with the top 3 players Sari Ayu, Mustika Ratu, and Seger holding only 23\%. This statistic concludes that consumer attachment to local brands in general might or might not differentiate a local brand's brand equity.

Thus, this study focuses on analyzing whether the attachment to localness really influences the brand equity of local brands by looking at the difference between customer-based brand equity of a local body moisturizer brand in the minds of two different groups, which are the highly ethnocentric one and the lowly ethnocentric one. The two groups come from the same pool for ease of investigation. This study adapts Bandara, et al (2012)'s study that investigated the relationship between consumer ethnocentrism and attitude towards foreign beer brands. The local brand under investigation in this study is a growing company with vision and mission-oriented operation, PT MustikaRatuTbk.

Based on psychological perspective, brand is viewed as a node in memory that is related to various different associations and with varied power. Consumers understand brand as a category that is always associated with specific attributes (Aryanto et al., 2009). There are two main models of brand equity in modern psychology. The first model is conceptualized by Aaker $(1991,1995)$, Aaker and Joachimsthaler (2000) and the other model came from Keller (1993, 2003). In Aaker's model brand equity is formulated from managerial and corporate strategic point of view although the main basis is consumer behavior. Aaker outlined brand asset contributing to the creation of brand equity in four dimension: brand awareness, perceived quality, brand associations and brand loyalty.

Consumer-Based Brand Equity (CBBE), as a model of brand equity with the core assumption of this model that the power of a brand lies on what is learnt, felt, seen, and heard about the brand by consumers as a result of the experience all the time (Keller, 2003). Based on this model, a brand is said to have positive Consumer Based Brand Equity if the consumer reacted more positively towards a product and how the product is marketed when the brand is identified, compared with when the product's brand is not identified. Key creation of brand equity is brand knowledge, brand awareness, and brand image. Brand equity is created when consumer has high awareness and familiarity towards a brand and has strong, positive, and unique brand association in memory.

Many studies have been conducted regarding consumers' responses towards brand such as studies about gym membership loyalty and tourism (Aryanto et.al, 2003, 2012, 2012; Yeong et al., 2007) even in the planning stages (Aryanto et al., 2012). Affecting consumer perception towards a brand, consumer ethnocentrism has emerged from the sociological phenomenon called "ethnocentrism" introduced by William G. Sumner in 1906. According to Sumner (1906), ethnocentrism is the "technical name for the view of things in which one's own group is the centre of everything and all others are scaled and rated with reference to it. In other words, ethnocentrism is a tendency of people to believe that their cultural or ethnic group is important and the other groups are evaluated primarily from the perspective of one's own culture." It is further elaborated by Adorno, Frenkel-Brunswik, Levinson, and Sanford (1950) as "ethnic centeredness" and emphasizes this 
phenomenon as the rigidity in accepting the culturally "alike", while rejecting the culturally "unlike". According to those definitions, a strong ethnocentric person may judge other groups in relation to the cultural dimensions of language, behavior, customs and religion of his or her own group.

Moreover, this study addresses this issue by investigating the influence of consumer ethnocentrism on Consumer-Based Brand Equity of a domestic brand in the mind of Indonesian Youth Females who are exposed to strong international environment. This research has purposes to investigate the factors relevant for the investigation of Consumer-Based Brand Equity of skin moisturizer according in Indonesian female youth, to cluster female youth skin moisturizer consumers based on consumer ethnocentrism, and to investigate the differences between consumer-based brand equity of local skin moisturizer brand of highly ethnocentric and low ethnocentric Indonesian female youth segment.

\section{RESEARCH METHODS}

Problem solving steps in this research were divided into two main steps. The first step was the pilot study in which factor analysis is employed to analyze relevant factors for skin moisturizer brand Consumer-based Brand Equity analysis. The second step was the core study in which cluster analysis and One-Way ANOVA are employed to cluster female respondents into two clusters based on their degree of ethnocentrism then to compare and contrast their respective Consumer-based brand equity towards a named domestic skin moisturizer brand, i.e. Mustika Ratu Skin Moisturizer.

Pilot study was conducted by distributing a self-administered questionnaire with 5 point Likert scale. The questionnaire contained 51 items of measurement of Brand Loyalty, Brand Awareness, Brand Association, Perceived Quality, and Overall Brand Equity, accumulated and summarized from 5 researchers following Aaker's concept of Consumer-based brand equity. The reason is that not all the items for measurement in all 5 researchers were relevant to skin moisturizer brand. Thus, an analysis on the relevance of all items and the needs to reduce such large number needs to be conducted. The 51 items would be further reduced to more relevant set that will be used in the Consumer-based brand equity section in the core study. All items in the questionnaire would mention Mustika Ratu skin moisturizer.

The pilot study questionnaire was distributed to 70 female respondents who were asked whether they use any brand of skin moisturizer (either body butter or body lotion) in the past one year. If their answer were yes, they would proceed to fill up the questionnaire. Results from the pilot study were analyzed using Exploratory Factor Analysis. All the 51variables would be reduced to a new number; and these numbers of items were included in section III of the second questionnaire. The second questionnaire had three major parts. The first was demographic section consisting of a form for name, age, major, monthly expenses excluding boarding house fee/any housing rental expenses and the skin moisturizer brand they use. The second section consisted of the CETSCALE taken from the original Shimp and Sharma (1987)'s scale to measure respondent's consumer ethnocentric tendency. The last part consisted of the items of Consumer-based brand equity obtained from the pilot study but at this core study the brand mentioned in the

Data from the core study would be first analyzed using K-means cluster. The data processed were only the data obtained from the second part of the questionnaire. Results from processed data would show 2 clusters based on consumer ethnocentric tendency. One is the cluster of consumers with high ethnocentric tendency and the other cluster is the cluster of consumers with low ethnocentric tendency. Respondents with higher mean scores would go for the highly ethnocentric cluster and vice versa. The division into two clusters was used in the next analysis. After being divided into two 
clusters, the data from the third section would be analyzed using one-way ANOVA analysis. Result would show the mean difference between each cluster's brand loyalty, perceived quality, brand awareness, brand association, and overall brand equity.

The final result would show whether there is significant difference between the two clusters i.e. higher Consumer-based brand equity mean score in all dimension in the cluster respondents with high ethnocentric tendency and lower Consumer-based brand equity of domestic skin moisturizer brand Mustika Ratu mean score in the lower ethnocentric tendency cluster. Results would be referred back to previous studies by Chryssochoidis, Krystallis, and Perreas (2007); Verlegh (2007); Yeong et al.,(2007); and Evanschitzky et al.,(2008) who highlighted that consumer ethnocentrism is a good predictor of consumers' evaluation of domestic and foreign goods, where ethnocentric consumers in favor of the former. Therefore, based on the two main steps in this research, Figure 1 shows framework of the research.

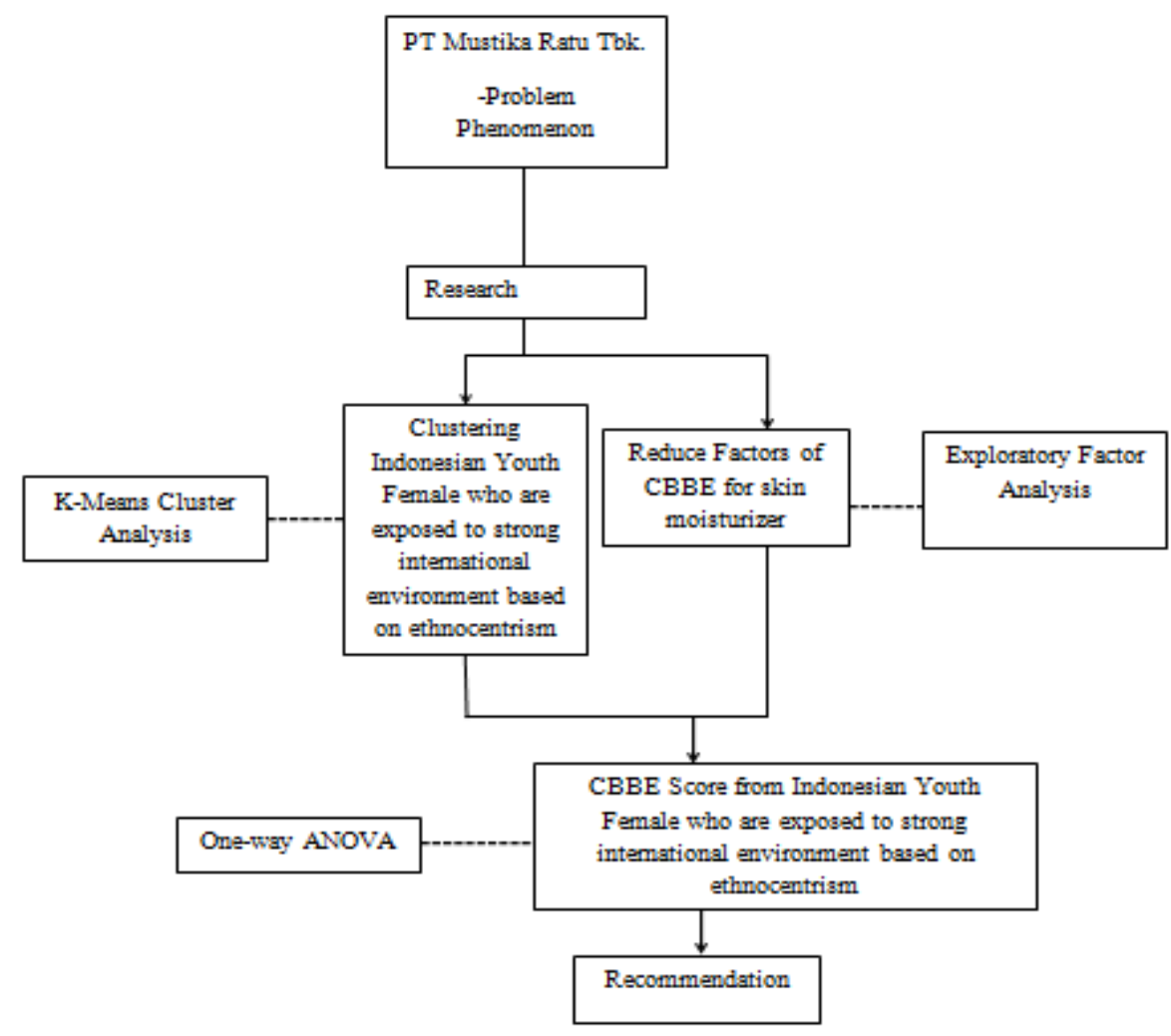

Figure 1 Research Logical Framework

\section{RESULTS AND DISCUSSION}

Measures of consumer ethnocentrism may provide PT Mustika Ratu Tbk. marketers with the information necessary to target consumers who do not allow nationalistic feelings to influence product quality evaluation and purchase behavior (Huddleston, Good, \& Stoel, 2001). Findings in this research lead to several implications. From Exploratory Factor Analysis, a set of 13 items consisting of 12 items of Multidimensional Brand Equity measurement and 1 item for Overall Brand Equity measure for skin moisturizer consumer-based brand equity is obtained. The 13 items are deemed relevant to be used for analysis in the later stage, i.e. cluster analysis and one way analysis of Variance (ANOVA). 
Based on cluster analysis using CETSCALE, female youth skin moisturizer consumers who are exposed to strong international environment can be clustered into 2 segments based on their consumer ethnocentrism tendency i.e. low tendency and high tendency consumers. The high ethnocentric consumer cluster have 61 members in the cluster and the low ethnocentric tendency have slightly less member i.e. 58 members in the cluster. The two clusters formed have significant difference as tested in the One Way ANOVA analysis. In all individual dimension analysis, all variable means and individual means show distinct difference between the high ethnocentric tendency consumer cluster and the low tendency one. The low ethnocentric consumer cluster tends to have lower mean score of Brand Loyalty, Perceived Quality, Brand Awareness, Brand Association and Overall Brand Equity toward Mustika Ratu skin moisturizers as compared to the high ethnocentric tendency cluster.

The distinct and consistent difference in the mean score of the high ethnocentric consumer cluster and the low ethnocentric consumer cluster is consistent with the finding of Shimp and Sharma (1987), Balabanis and Diamantopoulos (2004), and Bandara and Miloslava (2012). The finding claims that consumer ethnocentrism is positively correlated with preferences towards domestic products and negatively correlated with foreign-made product preference. Thus the positive correlation result in higher score of all mean score consumer-based brand equity dimensions (Brand Loyalty, Perceived Quality, Brand Awareness, and Brand Association) of Mustika Ratu skin moisturizer as a domestic product in the highly ethnocentric cluster and a lower score in the low ethnocentric cluster.

From the finding summary, it is affirmed that highly ethnocentric consumers will have positive perception towards domestic product and vice versa. It is suggested that the company to pay attention more on building consumer's brand loyalty as both high ethnocentric and low ethnocentric consumer show the lowest scores among the five dimensions of consumer based brand equity of Mustika Ratu skin moisturizer.

\section{CONCLUSION}

Exploratory Factor Analysis was employed to investigate the factors relevant for the investigation of Consumer-Based Brand Equity of skin moisturizer according to Indonesian female youth. By Exploratory Factor Analysis, 13 relevant items for skin moisturizer consumer-based brand equity analysis under 5 dimensions of Consumer-Based Brand Equity can be obtained from the original 51 points collated from 5 different researchers following Aaker's concept of Consumer-Based Brand Equity. The 13 variables can be employed for future research on Consumer-Based Brand Equity of skin moisturizer specifically.

Cluster analysis was employed to cluster female youth skin moisturizer consumers with strong exposure to international environment based on consumer ethnocentrism. By Cluster analysis, Indonesian youth female skin moisturizer consumers with high exposure of international environment can be clustered into 2 clusters, i.e. cluster of consumers with high ethnocentric tendency and cluster of consumers with low ethnocentric tendency with valid and distinct difference between the two clusters. The significance value concludes that there is a difference between the averages of consumer ethnocentrism score of the two clusters formed. The clustering process resulted in 61 respondents clustered into the high ethnocentric tendency cluster and 58 respondents clustered into the low ethnocentric tendency cluster.

One way analysis of Variance (ANOVA) is employed to investigate the differences between Consumer-based brand equity of local skin moisturizer brand of highly ethnocentric and low ethnocentric Indonesian female youth segment. By one way analysis of Variance, the two clusters 
formed have significant difference as tested in the One Way ANOVA analysis. In all individual dimension analysis (Brand Loyalty, Perceived Quality, Brand Awareness, Brand Association and Overall Brand Equity), all variable means and individual means show distinct difference between the high ethnocentric tendency consumer cluster and the low tendency one. The low ethnocentric consumer cluster all have lower mean score of Brand Loyalty, Perceived Quality, Brand Awareness, Brand Association and Overall Brand Equity towards Mustika Ratu skin moisturizers compared to the high ethnocentric tendency cluster.

\section{Suggestions}

The research gives a descriptive insight of the clustered nature of Indonesian youth female segment. The female youth segment in Indonesia is clustered into cluster of high ethnocentric tendency consumers and low ethnocentric tendency consumers. The lower tendency cluster tend to have much lower mean score of Brand Loyalty, Perceived Quality, Brand Awareness, Brand Association, and Overall Brand Equity as compared to their highly ethnocentric counterpart. In order to capture the low ethnocentric segment of female Indonesian youth, the company may apply several things as follow.

The first, the company needs to specifically increase the loyalty of low ethnocentric consumers, the company may strengthen its product function and branding efforts to send the message that the products have similar prowess to the foreign brands. The second, the company needs to specifically increase the perceived quality in the minds of low ethnocentric consumers, the company may try to strengthen its brand reliability in the minds of low ethnocentric consumers to send the message that MustikaRatu skin moisturizer is indeed a high quality product. The third, the company needs to specifically increase the brand awareness of low ethnocentric consumers, the company may try to increase its branding effort towards the low ethnocentric consumers such that the consumers may recall the characteristics and features of Mustika Ratu skin moisturizer. The fourth, the company needs to specifically increase the brand association of low ethnocentric consumers, the company may try to strengthen its company credibility image in the minds of low ethnocentric consumers thus the consumers may place more trust in the company for their daily need of skin moisturizer. The fifth, the company needs to specifically increase the overall brand equity in the minds of low ethnocentric consumers, the company may try to strengthen its brand value in the minds of low ethnocentric consumers such that they think of the product as a worthy purchase and of high value. The sixth, although this is consistent with the distrust nature of the low-ethnocentric consumers towards domestic brand, this provides an insight for the company to strengthen its brand value in the minds of low ethnocentric consumers.

For future research, to investigate further about the specific relationship between Brand Loyalty and consumer ethnocentrism, future research may discuss further as to which extent disloyalty of low ethnocentric consumer is affected by their global/local orientation. To investigate further about the specific relationship between Perceived Quality and consumer ethnocentrism, future research may discuss further as to which extent the distrust of low ethnocentric consumer is affected by their global/local orientation. To investigate further about the specific relationship between Brand Awareness and consumer ethnocentrism, future research may discuss further as to which extent the lack of brand recall of low ethnocentric consumer is affected by their global/local orientation. To investigate further about the specific relationship between Brand Association and consumer ethnocentrism, future research may discuss further as to which extent the lack of trust on the company of low ethnocentric consumer is affected by their global/local orientation. To investigate further about the specific relationship between Overall Brand Equity and consumer ethnocentrism, future research may discuss further as to which extent the low perception of brand value in low ethnocentric consumer is affected by their global/local orientation. 


\section{REFERENCES}

Aaker, D. A. (1991). Managing Brand Equity: Capitalizing on the Value of a Brand Name. New York: The Free Press.

Aaker, D. A. (1992). Managing the most important asset: brand equity. Planning Review, 20(5).

Aaker, D. A., \& A. Biel (Eds.) (1993). Brand Equity and Advertising. Hillsdale, NJ: Lawrence Erlbaum Associates.

Aaker, D. A. (1995). Building Strong Brands. New York: The Free Press.

Aaker, D. A. (1996). Measuring brand equity across products and markets. California Management Review, 38(3), 102-120.

Aaker, D. A., \& Jennifer. (1997). Dimension of Brand Personality. Journal of Marketing Research, 34(3), 347-356.

Aaker, D.A., \& Joachimsthaler. (2000). Brand Leadership: Building assets in an information economy. New York: Free Press.

Adorno, T. W., Frenkel-Brunswik, E., Levinson, D. J., \& Sanford, R. N. (1950). The Authoritarian Personality. New York: Harper and Row.

Aryanto, R. (2003). Environmental Marketing Pada Ekowisata Pesisir: Menggerakan Ekonomi Rakyat Daerah Otonom. Institut Pertanian Bogor: Program Pasca Sarjana S3.

Aryanto, R., Susanto, S., \& Santa Stefenny, L. (2009). Dampak Loyalitas dari Keputusan Konsumen disebabkan Pelayanan dan Promosi pada Usaha Gimnastik. The Winners, 10(2).

Aryanto, R., \& Fransiska, M. (2012). The role of government assistance to generate competitive leadership, commitment, motivation, innovation, environment and its impact on the performance of TenunCual Union Industry Cluster in Bangka Belitung Province. ProcediaSocial and Behavioral Sciences, 65, 167-172.

Aryanto, R., \& Gautama So, I. (2012). Perencanaan manajemen lanskap zonasi destinasi wisata budaya Kota Tua Jakarta. Binus Business Review, 3(2).

Balabanis, G., \& Diamontopoulos, A. (2004). Domestic country bias, country of-origin effects and consumer ethnocentrism: a multidimensional unfolding approach. J. Acad. Mark Sci., 32, 8095.

Bandara, W. W. M. C., \& Miloslava, C. (2012). Consumer ethnocentrism and attitudes towards foreign beer brands: With evidence from Zlin region in the Czech Republic. Journal of Competitiveness, 4(2), 3-19.

Chryssochoidis, G., Krystallis, A, Perreas, P. (2007). Ethnocentric beliefs and country-of-origin (COO) effect: impact of country, product and product attributes on Greek consumers' evaluation of food products. Eur. J. Mark., 41(11/12), 1518-1544. 
Evanschitzky, H., Wangenheim, F. V., Woisetschlager, D., \& Blut, M. (2008). Consumer ethnocentrism in the German market. Int. Mark. Rev., 25(1), 7-23.

Huddleston, P., Good, L. K., \& Stoel, L. (2001). Consumer ethnocentrism, product necessity and Polish consumers' perceptions of quality. International Journal of Retail \& Distribution Management, 29(5), 236-246.

Keller, K. L. (1993). Conceptualizing, measuring and managing customer-based brand equity. Journal of Marketing, 57(1), 1-9.

Keller, K. L. (2003). Strategic Brand Management: Building, Measuring and Managing Brand Equity, $\left(2^{\text {nd }}\right.$ ed). Upper Saddle River, NJ: Pearson Education International.

Shimp, T., \& Sharma, S. (1987). Consumer ethnocentrism: construction and validation of the CETSCALE. J. Mark. Res., 24(3), 280-289.

Sumner, W. G. (1906). Folkways. Boston: Ginn

Verlegh, P .W. J. (2007). Home country bias in product evaluation: the complementary roles of economic and socio-psychological motives. J. Int. Bus. Stud., 38, 361-373.

Yeong, N. C., Mohamad, O., Ramayah, T., \& Omar, A. (2007). Purchase preference of selected Malaysian motorcycle buyers: the discriminating role of perception of country of origin of brand and ethnocentrism. Asian Acad. Manage, 12(1), 1-22. 